\title{
A New Method for Normalization of Capillary Pressure Curves
}

\author{
S.E.D.M. Desouky ${ }^{1}$ \\ 1 King Saud University, College of Engineering, Petroleum Engineering Department, PO Box 800, Riyadh 11421 - Saudi Arabia \\ e-mail: desouky@ksu.edu.sa
}

\begin{abstract}
Résumé - Nouvelle méthode pour la normalisation des courbes de pression capillaire - Une nouvelle méthode pour la normalisation de données de pression capillaire d'un réservoir a été développée. Celle-ci incorpore les effets de géométrie de pore (distribution de taille de pores et indicateur de zone d'écoulement), de lithologie et de saturation irréductible en eau. L'approche par zone d'écoulement a été utilisée pour classifier le réservoir en zones de géométrie de pore constantes. La fonction de Leverett a été alors corrélée à la saturation en eau normalisée pour chaque zone de réservoir pour grouper les données de pression capillaire de cette zone sur une courbe de tendance. La méthode nécessite des mesures de pression capillaire, de saturation irréductible en eau, et des données classiques de pétrophysique telles que la perméabilité et la porosité.

Afin de vérifier la validité de la méthode proposée, les données de pression capillaire, saturation irréductible en eau, et des données classiques de pétrophysique de grès argileux dans le golfe de Suez (Égypte) ont été obtenues et utilisées pour déterminer la précision des relations développées. Les calculs ont montré que le réservoir étudié possède quatre zones de géométrie de pore constantes. Un excellent accord existe entre les données mesurées et celles calculées avec des erreurs relatives moyennes de $-5,8,-4,3$, 3,7 et $4,4 \%$ respectivement pour les zones de d'écoulement $1,2,3$ et 4 .
\end{abstract}

\begin{abstract}
A New Method for Normalization of Capillary Pressure Curves - A new method for normalization of capillary pressure data of a reservoir was developed that incorporates the effects of pore geometry (pore size distribution index and flow zone indicator index), lithology index and irreducible water saturation. The hydraulic flow unit's approach was used to classify the reservoir formation into constant pore geometry units. The Leverett J-function was then correlated with the normalized water saturation for each reservoir unit to group the capillary pressure data of that unit into one curve. The method requires the measurements of capillary pressure, irreducible water saturation, and routine core data such as permeability and porosity.

To check the validity of the proposed method, capillary pressure data, irreducible water saturations, and routine core data of a shaley-sandstone reservoir in the Gulf of Suez (Egypt) were obtained and were used in determining the accuracy of the developed equations. The calculations showed that the studied reservoir has four constant pore geometry units. An excellent agreement existed between the measured data and the calculated ones with average relative errors of - 5.8, - 4.3, 3.7 and 4.4\% for flow unit-1, unit-2, unit-3 and unit-4, respectively.
\end{abstract}




\section{NOMENCLATURE}

$\begin{array}{ll}a & \text { constant, Equation (7), Pa } \\ a_{1}, a_{2} & \text { constant, Equation (5) } \\ A & \text { constant, Equation (8), Pa } \\ b & \text { saturation exponent, Equation (7) } \\ B & \text { saturation exponent, Equation (8) } \\ C & \text { constant, Equation (5) } \\ \mathrm{FZI} & \text { flow zone indicator, } \mathrm{m} \\ g & \text { gravity acceleration, } \mathrm{m} / \mathrm{s}^{2} \\ h & \text { height above oil/water contact, } \mathrm{m} \\ J\left(S_{w}\right) & \text { Leverett } J \text {-function for capillary pressure } \\ J^{*} & \text { Lithology index } \\ K & \text { permeability, } \mathrm{m}^{2} \\ P & \text { pressure, Pa } \\ r & \text { pore entry radius, } \mathrm{m} \\ \mathrm{RQI} & \text { reservoir quality index, } \mathrm{m} \\ S & \text { saturation, pore volume fraction }\end{array}$

\section{Greek Letters}

$\begin{array}{ll}\theta & \text { contact angle } \\ \rho & \text { density, } \mathrm{kg} / \mathrm{m}^{3} \\ \sigma & \text { interfacial tension, } \mathrm{N} / \mathrm{m} \\ \Phi & \text { porosity, fraction } \\ \lambda & \text { pore size distribution index } \\ \Psi & \text { constant, Equations }(17,18)\end{array}$

\section{Subscripts}

$\begin{array}{ll}c & \text { capillary } \\ n & \text { normalized } \\ n w & \text { non-wetting phase } \\ o & \text { oil } \\ w & \text { water } \\ w n & \text { normalized water saturation } \\ w r & \text { irreducible water saturation. }\end{array}$

\section{INTRODUCTION}

The capillary phenomenon occurs in porous media when two or more immiscible fluids are present in the pore space. The capillary pressure is defined as the difference in pressure between the non-wetting and wetting phases [1].

$$
P_{c}=P_{n w}-P_{w}
$$

For oil and water:

$$
P_{c}=P_{o}-P_{w}
$$

Since the gravity forces are balanced by the capillary forces, capillary pressure at a point in the reservoir can be estimated from the height above the oil-water contact and the difference in fluid densities. For an oil-water system:

$$
P_{c}=g h\left(\rho_{o}-\rho_{w}\right)
$$

Capillary pressure curves are usually determined in the laboratory by three methods: mercury injection, restored state cell (porous plate) and centrifuge. The description of these methods can be found in the reservoir text books [1,2].

Reservoir calculations require a normalized curve for the capillary pressure measurements which are obtained from several plug samples that at different depths. Because of the reservoir heterogeneity, no single capillary pressure curve can be used for the entire reservoir. Attempts were made to correlate capillary pressure curves with the petrophysical properties of the reservoir rock. Leverett [3] was the first to introduce a dimensionless capillary pressure correlation function. This function is defined as:

$$
J\left(S_{w}\right)=P_{c} \sqrt{ } K / \varphi /(\sigma \cos \theta)
$$

The above function accounts for change of permeability, porosity and wettability of the reservoir as long as the general pore geometry remains constant. This fact was confirmed by Brown [4], and Rose and Bruce [5]. Guthrie and Greenberger [1] proposed a linear correlation of the water saturation with porosity and permeability at a constant value of capillary pressure.

$$
S_{w}=a_{1} \varphi+a_{2} \log K+C
$$

Wright and Woody [6] applied this correlation to a group of capillary pressure curves of different permeabilities, but with constant porosity. Pletcher [7] suggested the use of Equation (5) to averaging capillary pressure curves corresponding to average permeability and porosity. El-Khatib [8] modified the $J$-function by introducing tortuosity and irreducible water saturation for averaging capillary pressure data.

$$
\begin{gathered}
J^{*}\left(S_{w}\right)=P_{c} \sqrt{ } K / \varphi\left(1-S_{w r}\right) /(\sigma \cos \theta) \\
P_{c}=a /\left(S_{w}-S_{w r}\right)^{b}
\end{gathered}
$$

Equation (6) requires the equality of the saturation exponent $b$ in the different formations to obtain a unique correlation. Khairy [9] proposed a power relationship between capillary pressure and saturation:

$$
P_{c}=A S_{w}^{-B}
$$

Although the above relation correlated the data with acceptable degree of accuracy, it fails to correlate capillary pressure data of another formation. Donaldson et al. found that the least square solution of a hyperbolic function can be used to average capillary pressure data. Thus the proposed models, discussed above, apply locally only because there may be large differences in depositional characteristics at other locations. Most of the models explicitly ignore the scatter of data about the normalized capillary pressure curve 
and implicitly attribute any scatter to measurement errors, fluctuations in reservoir characteristics, or absence of some reservoir parameters. An improvement to $J$-function, Equation (4), can be achieved by first identifying lithological categories of formation and then calculating regression curves for measurements that belong to each lithology class. The proper method to identify the different lithological categories is the use of hydraulic flow unit technique.

\section{THEORETICAL ANALYSIS}

A more reasonable approach for normalizing capillary pressure data is to attribute the nature of interdependency between capillary pressure and saturation to geological variations in the reservoir rock and seek functional relationships for capillary pressure that capture geological controls on flow properties. Such relationships are best achieved if rocks of similar fluid conductivity are identified and grouped together. Each group is referred to as a hydraulic flow unit. The hydraulic flow unit is a reservoir zone that is continuous laterally and vertically and has similar flow and bedding characteristics. The hydraulic flow unit that characterized a specific reservoir zone is mathematically expressed by [10].

$$
\mathrm{RQI}=\mathrm{FZI} \Phi_{n}
$$

Where the reservoir quality index (RQI) is given by:

$$
\mathrm{RQI}=\sqrt{ } K / \Phi
$$

And the normalized porosity $\left(\Phi_{n}\right)$ is defined as:

$$
\Phi_{n}=\Phi /(1-\Phi)
$$

The value of flow zone indicator (FZI) is the intercept of a unit-slope line with the coordinate $\Phi_{n}=1$, on a log-log plot of RQI versus $\Phi_{n}$. The basic idea of hydraulic flow unit classification is to identify groupings of data classes that form straight lines with unit slope on log-log plot of RQI versus $\Phi_{n}$. From Equations (9) and (10), the term $\sqrt{ }_{K} / \Phi$ is given by:

$$
\sqrt{ } K / \Phi=\text { FZI } \Phi_{n}
$$

Substituting Equation (12) in Equation (4), one gets:

$$
J\left(S_{w}\right)=P_{c} \text { FZI } \Phi_{n} /(\sigma \cos \theta)
$$

For capillary pressure data of a constant pore geometry (i.e. a fixed value of FZI), the relationship between the values of $J\left(S_{w}\right)$ and normalized water saturation $\left(S_{w n}\right)$ is given by:

$$
J\left(S_{w}\right)=J * S_{w n}{ }^{-1 / \lambda}
$$

Where,

$$
S_{w n}=\left(S_{w}-S_{w r}\right) /\left(1-S_{w r}\right)
$$

The term $J^{*}$ is known as the lithology index and its value is equal to $J\left(S_{w}\right)$ at $S_{w n}=1$. The term $\lambda$ is the pore size distribution index which is equal to the reciprocal of the slope.
Substituting Equation (11) in Equation (13), one obtains:

$$
P_{c}=\sigma \cos \theta J^{*} S_{w n}{ }^{-1 / \lambda} /\left(\mathrm{FZI} \Phi_{n}\right)
$$

Equation (16) can be rewritten as follows:

$$
P_{c}=\Psi S_{w n}^{-1 / \lambda} / \Phi_{n}
$$

Where the term $\Psi$ is constant for each hydraulic flow unit, and is defined by:

$$
\Psi=\sigma \cos \theta J^{*} / \mathrm{FZI}
$$

Equation (17) is the normalized capillary pressure equation for a flow unit of a reservoir, and the number of the normalized curves is equal to that of the hydraulic flow units.

\section{Calculations Procedure}

Given the routine core data ( $k$ and $\Phi)$, capillary pressure data $\left(P_{c}-S_{w}\right)$, and irreducible water saturation $\left(S_{w r}\right)$, the following steps are proposed for normalizing the capillary pressure curves.

- Calculate the values of RQI and $\Phi_{n}$ from core data using Equations (10) and (11), respectively.

- Plot RQI versus $\Phi_{n}$ on log-log plot, determine the optimum number of hydraulic flow units using the iterative multi-linear regression clustering technique (10), and then determine the values of FZI for each unit.

- Identify the capillary pressure data of each flow unit, noting that the capillary pressure data of a flow unit are corresponding to the core data of that unit.

- Use the capillary pressure data and core data to calculate the values of $J$-function and normalized water saturation from Equations (4) and (15), respectively.

- Plot the values of $J$-function against normalized water saturation on log-log scale, and then determine the values of lithology index $\left(J^{*}\right)$ and pore size distribution index $(\lambda)$, for each flow unit.

- Determine the normalized curve equation for each unit, using Equations (17) and (18).

\section{APPLICATION TO FIELD DATA}

In this study, routine core data ( $k$ and $\Phi)$, capillary pressure data $\left(P_{c}-S_{w}\right)$, and irreducible water saturation $\left(S_{w r}\right)$ were obtained from a shaley-sandstone reservoir in the Gulf of Suez, Egypt. The reservoir thickness is $70 \mathrm{~m}(229.66 \mathrm{ft})$, including $56 \mathrm{~m}(183.73 \mathrm{ft})$ shaley-sandstone and $14 \mathrm{~m}$ $(45.93 \mathrm{ft})$ shale. The routine core data were 344 measurements and 44 data-sets of capillary pressure data and irreducible water saturation. The method used for measuring capillary pressure and irreducible water saturation is the restored state cell (porous plate), which relies on the selection of a suitable porous plate (porcelains) to provide a barrier that 
TABLE 1

Statistical analysis of reservoir parameters

\begin{tabular}{|c|c|c|c|}
\hline Item & $\begin{array}{c}\text { Permeability, mD } \\
\left(1.013 \times 10^{9} \cdot \mathrm{m}^{2}\right)\end{array}$ & Porosity (fraction) & $\begin{array}{c}\text { Irreducible water } \\
\text { saturation (fraction }(p v))\end{array}$ \\
\hline Mean & 351.4 & 0.137 & 0.114 \\
\hline Standard error & 21.9 & 0.003 & 0.004 \\
\hline Median & 148.9 & 0.123 & 0.112 \\
\hline Mode & 105.3 & 0.197 & - \\
\hline Standard deviation & 406.9 & 0.052 & 0.024 \\
\hline Sample variance & 165576.8 & 0.003 & 0.001 \\
\hline Kurtosis & 3.5 & 0.119 & -1.160 \\
\hline Skewness & 1.8 & 0.730 & 0.068 \\
\hline Range & 2151.4 & 0.280 & 0.080 \\
\hline Minimum & 14.3 & 0.02 & 0.08 \\
\hline Maximum & 2165.7 & 0.30 & 0.16 \\
\hline Sum & 120879.1 & 47.112 & 5.026 \\
\hline Count & 344.0 & 344 & 44 \\
\hline Largest (1) & 2165.7 & 0.298 & 0.159 \\
\hline Smallest (1) & 14.3 & 0.022 & 0.076 \\
\hline Confidence level (95.0\%) & 43.2 & 0.005 & 0.007 \\
\hline
\end{tabular}

permits the passage of the wetting phase which is the simulated formation brine (i.e drainage process). The following procedure was proposed by International Core Laboratories [11] for measuring the capillary pressure by restored state cell (porous plate).

- Clean, dry core samples are evacuated and pressure saturated with the simulated formation brine.

- The porous plate is saturated with the simulated formation brine.

- The saturated core samples are placed on the porous plate with a suitable material (tissue paper and diatomaceous earth) to aid in establishing a good capillary contact between the rock surface and porous plate.

- The pressure applied to the assembly is increased by small increments, and each sample is allowed to approach a state of static equilibrium at each pressure level. This aids in controlling the wettability of the rock sample.

- The saturation of the core is calculated at each point gravimetrically.

The routine core data ( $k$ and $\Phi$ ) and irreducible water saturation $\left(S_{w r}\right)$ were statistically analyzed and the results are given in Table 1 . The capillary pressure data are plotted in Figure 1. It shows a lot of scatter which clearly indicates the existence of more than one rock type. A normalization of these data was attempted using $J$-function (Eq. (4)). The normalized curve is overlaid on the capillary pressure data in Figure 1, and the average relative error between the measured data and those calculated from the normalized curve equation was found be $37.6 \%$. The existence of more than one rock type or simply pore geometry in the studied reservoir can also be confirmed by plotting $\log k$ versus $\Phi$, as shown in

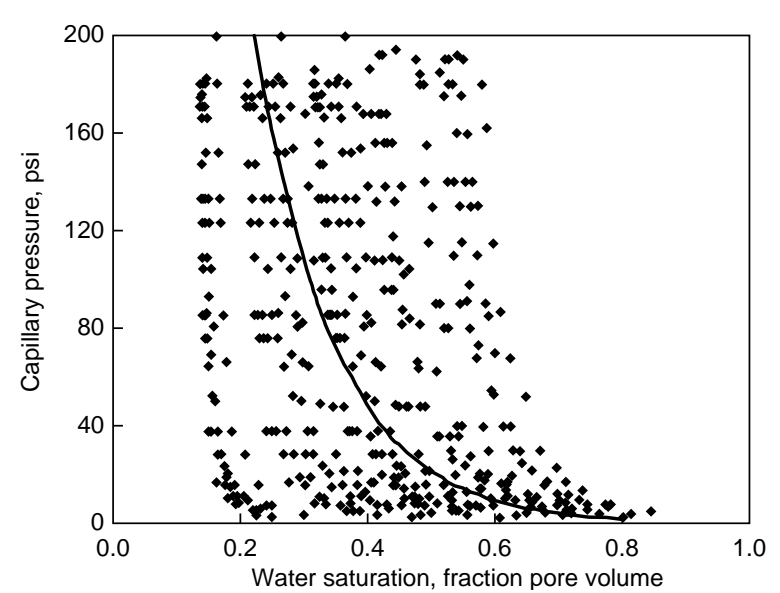

Figure 1

Capillary pressure data of the studied reservoir.

Figure 2. This figure shows a poor correlation between porosity and permeability $\left(r^{2}=0.339\right)$, and consequently a wide variation in pore geometry existed in this reservoir. The variation in pore geometry can best be quantified by using hydraulic flow unit the technique.

\section{RESULTS AND DISCUSSION}

By applying iterative multi-linear regression clustering [10] to the core data given in Figure 2, the optimum number of hydraulic flow units is four. Core data of each flow unit is 


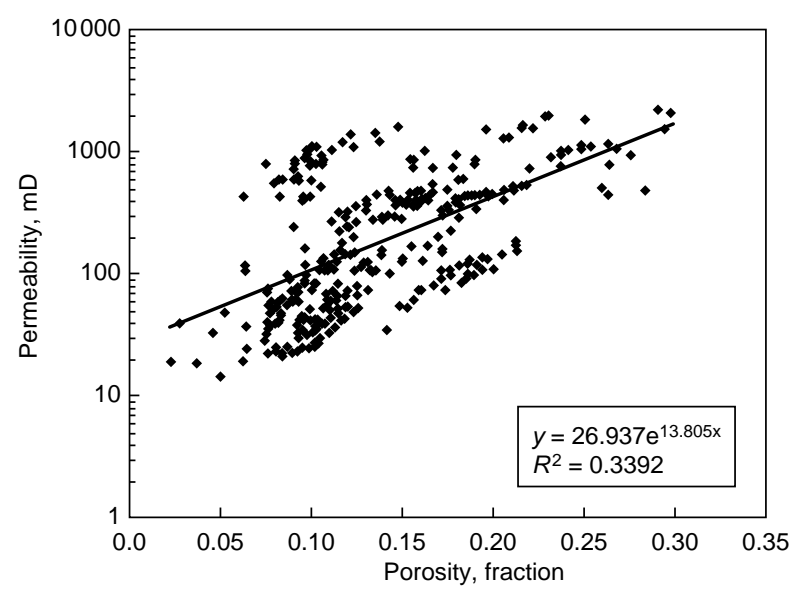

Figure 2

Routine core data of the studied reservoir.

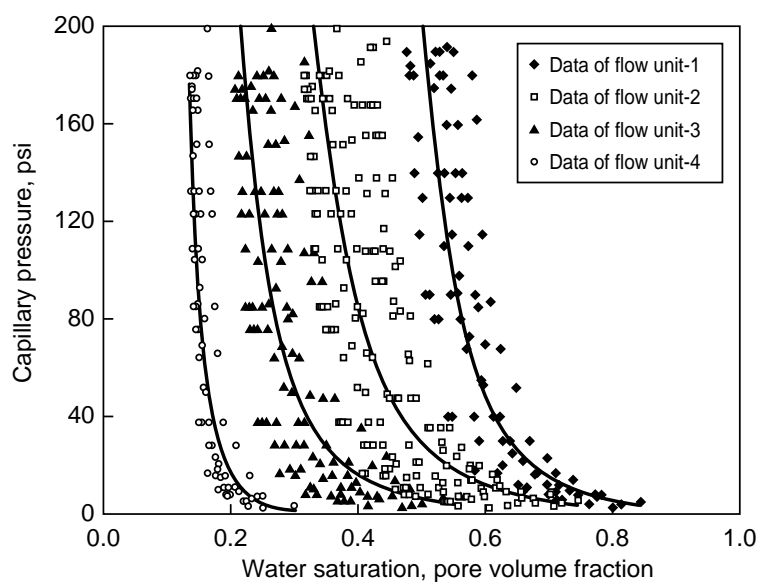

Figure 4

Capillary pressure data of the four flow units reservoir.

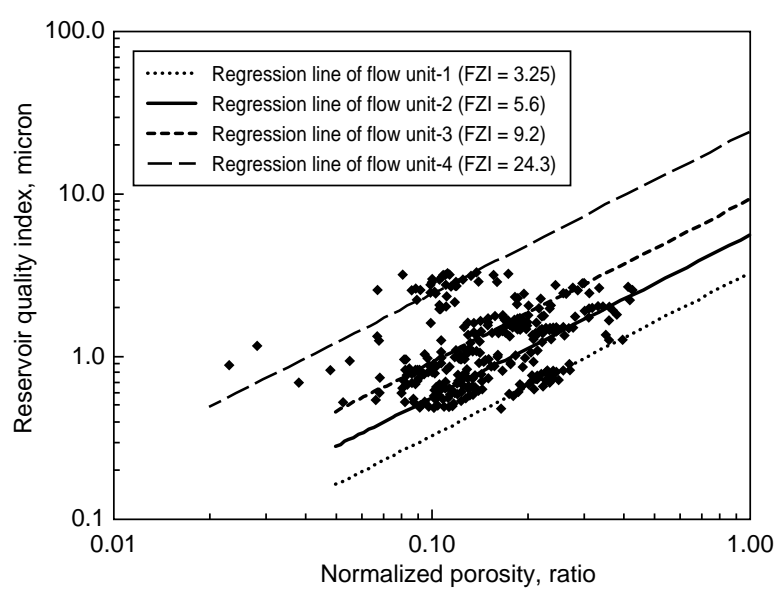

Figure 3

Reservoir quality index $v s$ normalized porosity.

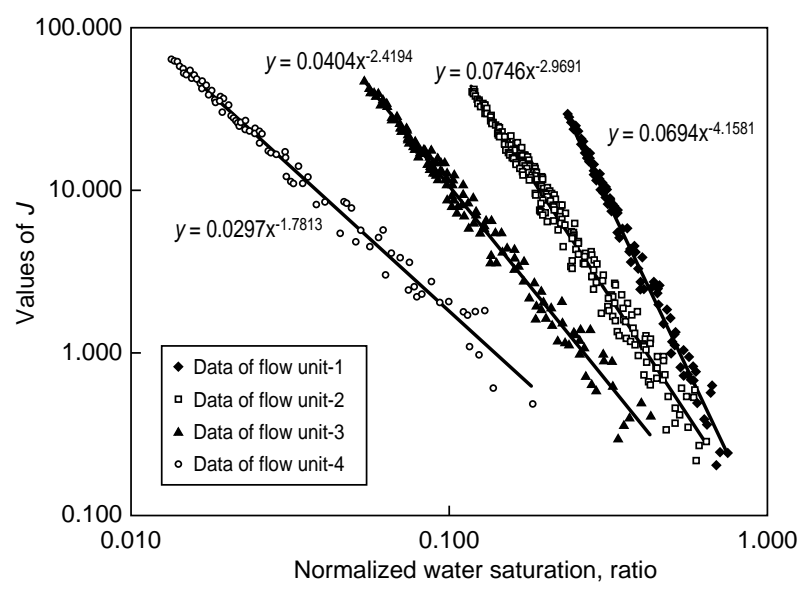

Figure 5

Values of $J$-function $v s$ normalized water saturation. assigned to a regression line with a fixed value of flow zone indicator, and is also characterized by a constant pore geometry, as shown in Figure 3. The flow zone indicators are 3.25, 5.6, 9.2 and 24.3 micron for unit-1, unit-2, unit-3 unit-4, respectively. Based on the core data of each flow unit and plug-depths, the capillary pressure data and irreducible water saturations are sub-grouped into four sets of data. These four sets of data are plotted in Figure 4. To determine the values of lithology index $\left(J^{*}\right)$ and pore size distribution index $(\lambda)$ from capillary pressure data and irreducible water saturations, the values of $J$-function ( $E q .4)$ and normalized water saturation (Eq. 15) are calculated and plotted in Figure 5. This figure ensures the existence of four different pore geometry rocks and the values of $J^{*}$ and $\lambda$ are given in Table 2 . The table shows that the results of pore size distribution and lithology index are consistent with those plotted in
Figure 3. However, unit-4 represents the highest rock quality and a good pore size distribution. Using the results of Table 2 , the four equations of the normalized curves for four sets of capillary pressure data are given in Table 3 . These equations were used to calculate capillary pressure data in each reservoir unit using the same flow unit's characteristics. Figure 6 shows a cross-plot between the measured capillary pressure data and calculated ones. The figure indicates an excellent agreement between the measured and those calculated from Equation (17) with average relative errors of $-5.8,-4.3,3.7$ and $4.4 \%$ for capillary pressure data of flow unit-1, unit-2, unit-3 and unit-4, respectively. The results ensure the reliability of the proposed technique for normalizing capillary pressure data which in turn enhances reservoir description and simulation studies. 
TABLE 2

Characteristics of the reservoir four flow units

\begin{tabular}{c|c|c|c}
\hline Flow unit & Flow zone indicator (FZI) (micron) & Lithology index $\left(J^{*}\right)$ & Pore distribution index $(\lambda)$ \\
\hline Unit-1 & 3.25 & .069 & .258 \\
\hline Unit-2 & 5.6 & .075 & .386 \\
\hline Unit-3 & 9.2 & .040 & .467 \\
\hline Unit-4 & 24.3 & .030 & .593 \\
\hline
\end{tabular}

TABLE 3

Normalized equations of the capillary pressure data

\begin{tabular}{c|c}
\hline Flow unit & Normalized curve equation, psi $(0.145 \mathrm{kPa})$ \\
\hline Unit-1 & $P_{c}^{*}=0.223 /\left(S_{w n}{ }^{3.878} \Phi_{n}\right)$ \\
\hline Unit-2 & $P_{c}=0.139 /\left(S_{w n}^{2.574} \Phi_{n}\right)$ \\
\hline Unit-3 & $P_{c}=0.046 /\left(S_{w n}^{2.141} \Phi_{n}\right)$ \\
\hline Unit-4 & $P_{c}=0.013 /\left(S_{w n}^{1.687} \Phi_{n}\right)$ \\
\hline
\end{tabular}

*The value of $(\sigma \cos \theta)$ is equal to 72 dyne/cm for air/brine system.

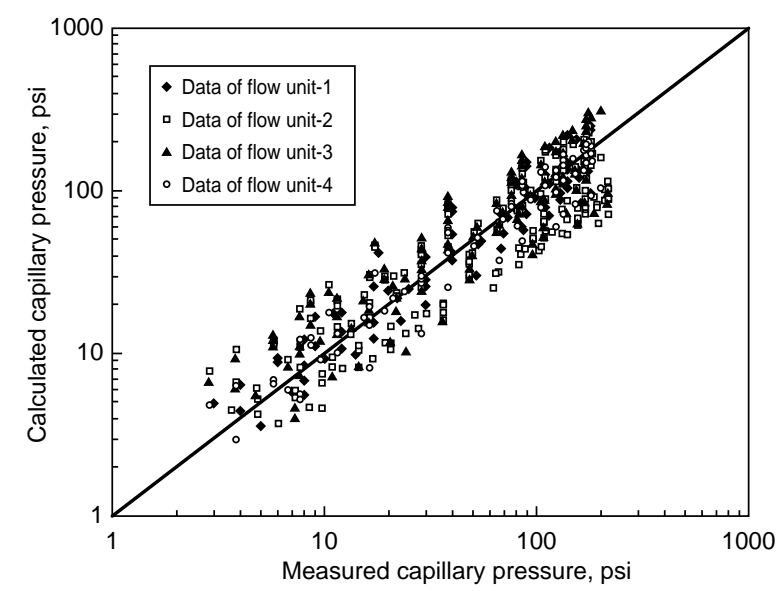

Figure 6

A crossplot between measured capillary pressures and calculated ones.

\section{CONCLUSIONS}

A new method for normalization of capillary pressure data, using Leverett $J$-function and hydraulic flow unit approach, was developed. The method incorporates the effects of pore geometry, lithology variation and fluid saturations.
The proposed technique is successfully applied to field data of a shaley-sandstone reservoir in the Gulf of Suez, Egypt. The average relative errors between measured data and the calculated ones were $-5.8,-4,3.7$ and $4.4 \%$ for flow unit-1, unit-2, unit-3 and unit-4, respectively.

The developed equations can be used to correlate capillary pressure data of different zones in a formation in the different wells according to the value of flow zone indicator (FZI) as determined from core data measured on plug samples taken from different wells.

\section{REFERENCES}

1 Amyx, J.W., Bass, D.M. and Whiting, R.L. (1960) Rock Properties: Petroleum Reservoir Engineering, McGraw-Hill Book Co. Inc., New York.

2 Tiab, D. and Donaldson, E.C. (1996) Petrophysics: Theory and Practice of Measuring Reservoir Rock and Fluid Transport Properties, Gulf Publishing Co., Houston, Texas.

3 Leverett, M.C. (1941) Capillary Behavior in Porous Solids. Trans. AMIE, 142, 152-169.

4 Brown, H.W. (1951) Capillary Pressure Investigation. Trans. AMIE, 192, 67-74.

5 Rose, W. and Bruce, W.A. (1944) Evaluation of Capillary Characters in Petroleum Reservoir Rocks. Trans. AMIE, 186, 127-142.

6 Wright, H.T. and Woody, L.D. (1955) Formation Evaluation of the Borregas and Seeligson Field: Brooks and Jim Wells County Texas. Symposium on Formation Evaluation, AIME, 27-28 October.

7 Pletcher, J.L. (1994) A Practical Capillary Pressure Correlation Technique. JPT, 46, 7, 556-562.

8 El-Khatib, N. (1995) Development of a Modified Capillary Pressure J-Function. Paper No. 29890 presented at SPE Conference, Bahrain, 11-14 March.

9 Khairy, M. (2001) New Technique for Determining the Average Capillary of a Reservoir. Oil-Gas European Magazine, 27, 1, 26-29.

10 Al-Ajmi, F.A. and Holditch, S.A. (2000) Permeability Estimation Using Hydraulic Flow Units in a Central Arabia Reservoir. Paper No. 63254 presented at SPE Conference, Texas, 1-4 October.

11 International Core Laboratories (1986) Special Core Analysis, Operating Manual, Aberdeen, UK.

Final manuscript received in September 2003 